\title{
BIOAVAILABILITY OF ORGANIC MINERALS (BIOBLEX) IN RABBITS FED EXCESS LEVELS OF DIETARY MINERALS AND EFFECTS ON REPRODUCTIVE PERFORMANCE, UNDER EGYPTIAN CONDITIONS. \\ Gad Alla, S.A.; A. A. Sedki; M. Abou Elaa and H. A. Abou Khashaba \\ Animal Production Research Institute, Agricultural Research Center, Giza, Egypt.
}

\section{ABSTRACT}

Eighty primiparous Bauscat doe rabbits, aged 10-11 months with an average initial body weight, $3886.84 \pm 64.79 \mathrm{~g}$ and 24 fertile Buck rabbis aged 6-7 months with an average initial body weight3123.75 $\pm 119.28 \mathrm{~g}$ were divided randomly into four comparable groups. The $1^{\text {st }}$ group was used as control contained a common trace mineral supplement ( $\mathrm{Fe}, \mathrm{Zn}, \mathrm{Cu}$. Mn and $\mathrm{Co}$ ) in Vitamin and Mineral primed and $2^{\text {nd }}$, $3^{\text {rd }}$ and $4^{\text {th }}$ groups contained Bioplex trace minerals products (Bioplex ${ }^{\mathrm{TM}}$ ) at $25 \%$, $50 \%$ and $100 \%$ of the common trace mineral supplemented levels, respectively. Number of services per conception, litter size, litter weight $(\mathrm{g})$, bunny weight $(\mathrm{g})$ at birth, 21 and 28 days were recorded. Semen quality of bucks was determined including ejaculate volume $(\mathrm{ml})$, wave motion (scores), sperm motility (\%), sperm concentration $\left(\times 10^{6} / \mathrm{ml}\right)$, dead and abnormal spermatozoa (\%) .

Litter weight at 21 days, 28 days of age, mean bunny weight at birth and at 21 days and litter weight gain from birth up to 28 days were significantly higher ( $P$ $<0.05$ ) with supplemented group at level of $50 \%$ of Bioplex ${ }^{\mathrm{TM}}$ than the treated groups with $25 \%$ and $100 \%$ of Bioplex ${ }^{\mathrm{TM}}$ and untreated does (control). However, number of services per conception, gestation length, litter size at birth, 21 and at weaning (28 days) and litter weight at birth, mean bunny weight at 28 days, litter weight gain from 21 to 28 days and pre-weaning mortality rate were insignificantly affected by supplementation of Bioplex ${ }^{\mathrm{TM}}$.

Most of doe and offspring traits were not affected significantly by the number of parity of Bouscat doe rabbits. However, mean bunny weight at birth and litter weight gain from 21 to 28 days were significantly $(P<0.05)$. Pre-weaning mortality percentage from birth to 28 days were lower significantly $(P<0.05)$ in the $1^{\text {st }}$ parity than in the $2^{\text {nd }}$ ones.

Level of blood serum total protein, urea-N, aspartate aminotransferase (AST), alanine aminotransferase $(A L T)$ were significantly $(P<0.01$ or $P<0.05)$ higher in doe rabbis supplemented with Bioplex ${ }^{\mathrm{TM}}$. However, level of blood serum total lipids, and cholesterol were significantly lower $(P<0.01)$ in rabbits treated with $50 \%$ and $100 \%$ Bioplex $^{\mathrm{TM}}$ as compared to those of treated with $25 \%$ Bioplex $^{\mathrm{TM}}$ or those of the control group. Levels of blood serum creatinine, serum blood minerals $(\mathrm{Ca}, \mathrm{P}, \mathrm{K}, \mathrm{Na}, \mathrm{Ca} / \mathrm{P}$ and $\mathrm{Na} / \mathrm{K}$ )and serum blood hormones (progesterone and prolactin) were not affected significantly by supplemental levels of Bioplex ${ }^{\mathrm{TM}}$.

Supplementation of Bioplex ${ }^{\mathrm{TM}}$ significantly $(\mathrm{P}<0.01$ or $\mathrm{P}<0.050$ improved semen quality of buck rabbits. The buck rabbits received the additional level of $100 \%$ Bioplex $^{\mathrm{TM}}$ showed the best physical semen characteristics as compared to buck rabbits received the additional level of $25 \%$ and $50 \%$ of Bioplex ${ }^{\mathrm{TM}}$ and AST was the highest one, while, cholesterol and ALT were $(P<0.05$ or $P .01)$ the lowest one. However, levels of blood serum AST significantly $(P<0.05)$ higher in the buck rabbits fed diets supplemented with the level of $100 \%$ of Bioplex ${ }^{\mathrm{TM}}$ than the other groups.

Keywords: Bioplex ${ }^{\mathrm{TM}}$, doe traits, physical semen characteristics, blood constituents. 
Gad Alla, S.A. et al.

\section{INTRODUCTION}

Traditional rabbit diets in which large amounts of animal proteins were used probably needed little minerals supplementation. At the present time, ration in which the major constituents are cereals and plant proteins do, however, require supplementing with trace and major minerals (Lang, 1981).Trace elements are essential for the function of various enzymes and other protein and it have biochemistry and physiology effects on parameters of fertility. Also, trace minerals played very important role for growth performance of growing rabbits and reproductive efficiency of does and their young (NRC, 1977). Bioplex is a commercial organic mineral mixture used as additive that provides $\mathrm{Fe}, \mathrm{Zn}, \mathrm{Cu}$. $\mathrm{Mn}$ and $\mathrm{Co}$ for poultry and rabbits. However, the effect of such a compound on growth performance and reproductive efficiency of rabbits under the conditions of Egypt is no studied yet

These minerals can pose problems, as they may become toxic to some sensitive fish species (Besser, 2001). Additionally, heavy metals tend to accumulate in the food chain and pose a toxicity problem to sensitive animal species, such as sheep. Feeding minerals with higher bioavailability and feeding to meet the specific requirements of the target animal can substantially reduce the amount of the mineral excreted and thereby the environmental risk when manure is applied to soils.

Leeson (2003) found that using trace minerals with greater bioavailability (Bioplex ${ }^{\mathrm{TM}}$ trace minerals) did not affect body weight gain and had little effect on feed efficiency of broilers even when fed at $20 \%$ of the inorganic trace mineral level. Bioplex ${ }^{\mathrm{TM}}$ can be utilized at a much lower concentration in the diet than inorganic minerals, without an impact on performance, while also decreasing the excess mineral excretion.

The Bioplex Trace Minerals allow maximum absorption and storage in body tissues to provide the essential reserve of nutrients at times of greatest need. Recent studies have demonstrated that, even where animals are supplemented at the published allowances for trace minerals, replacement of the inorganic sources with Bioplex Trace Minerals has yielded significant improvements in performance.

Zinc is on of such trace elements, it is essential for biological functions of all living matter and is necessary for growth, appetite, testicular maturation, skin integrity, mental activity, wound healing and immunocompeteence (Hahn and Baker, 1993, Barceloux, 1999), DNA and nutrients metabolism (Panerjee, 1988), immunity protection (Gross et al., 1979), fertility (Apgar, 1971 and Fizgerald et al., 1986) and many of other physiological processes. It is required for the metabolic activities or over 300 metaloenzymes and hormones (Abdel Mageed and Oehme, 1990). It is lone involved in processes of cell division, development and differentiation and in the control of gene expression (Leonhard- Marek, 2000). Iron is one of most important mineral elements in human and animal nitration. It is a component of haemoglobin and myoglobin, and of the enzymes, cytochromes, catalases, peroxidases and ribonucleotide reductase. Therefore, iron serves important function in 
oxygen transport and metabolism and synthesis of neurotransmitters and DNA (Youdin and Green, 1977). Limited information is available on the deleterious effects of excess dietary iron for rabbits that might result from excessive use of mineral supplements in the manufactured dies. Copper as essential element has been used as a feed additive for rabbits under moderate condition to improve growth rate and reduce enteric disease ( King, 1975).

The present study was performed to study the effect of supplementation of Bioplex ${ }^{\mathrm{TM}}$ as a commercial organic mineral mixture on some physiological and reproductive parameters of Bouscat rabbits.

\section{MATERIALS AND METHODS}

The present study was carried out at El-Gemeza Experimental Station, Animal Production, Research Institute, Ministry of Agriculture, Egypt. It started in November, 2004 and lasted 6 months. In this respect, eighty primiparous Bauscat doe rabbits, aged 10-11 months with an average initial body weight, $3886.84 \pm 64.79 \mathrm{~g}$ and 24 fertile Buck rabbis aged 6-7 months with an average initial body weight $3123.75 \pm 119.28 \mathrm{~g}$ were divided randomly into four comparable groups. All rabbits were fed on a basal pelleted ration. The $1^{\text {st }}$ group was used as control contained a common trace mineral supplement ( $\mathrm{Fe}, \mathrm{Zn}, \mathrm{Cu} . \mathrm{Mn}$ and $\mathrm{Co}$ ) in Vitamin and Mineral Premix and $2^{\text {nd }}, 3^{\text {rd }}$ and $4^{\text {th }}$ groups contained Bioplex trace minerals products (Bioplex ${ }^{\mathrm{TM}}$ ) at $25 \%, 50 \%$ and $100 \%$ of the common trace mineral supplemented levels, respectively.

Mating was carried out at random between does and bucks in the same group and each doe was transformed to the buck's cage to be mated and returned back to its cage after mating. The experimental rabbits were allotted in a windowed house. Flat desk cages $(60 \times 55 \times 40 \mathrm{~cm})$ provided with galvanized nests for does, feeders and drinker nipples. All kindling kits were remained in the nests with their dams for suckling from birth up to weaning at 28 days of age. All animals were kept under the same environmental and managerial conditions. The basal ration was formulated in one of feed mills to meet the nutrient requirements of rabbits according to NRC (1977). The ration was offered to rabbits ad libitum. The ingredients and chemical composition of the pelleted ration are shown in Table (1). The samples of pelleted diet were analyzed according to A. O. A. C. (1990).

Number of services per conception, litter size, litter weight $(\mathrm{g})$, bunny weight $(\mathrm{g})$ at birth, 21 and 28 days were recorded.

At eight month of age semen samples were individually collected from the bucks once weekly for a period of 5 weeks by using an artificial vagina. Semen quality of bucks was determined including ejaculate volume $(\mathrm{ml})$, wave motion (scores), sperm motility (\%), sperm concentration (x 10\%/ml), dead and abnormal spermatozoa (\%) as described by El-Gaafary (1987) and El-Kelawy (1993).

In the last week of the experiment, blood samples were collected from marginal ear vein under vacuum in glass tubes ( 3 does and 3 bucks /group) . Blood samples were left to clott centrifugated at 3000 r.p.m. for 15 minutes, 
Gad Alla, S.A. et al.

blood serum was carefully separated and stored frozen $\left(-20^{\circ} \mathrm{C}\right)$ in plastic vials until the biochemical analysis. Levels of serum total protein, total lipids, cholesterol, Ca, P. K and Na were determined according to Henery (1964) using commercial kits obtained from Diamond Diagnostics. Urea-N and creatinine concentration were determined by using commercial Kits of Diamond Diagnostics according to the method of Henery (1974). The activity of aspartate aminotransferase (AST) and alanine aminotrnsferase (ALT) was assayed according to the method described by Reitman and Frankel (1957).

Table 1: Ingredients and chemical composition of the experimental rations.

\begin{tabular}{lc}
\hline Items & $\%$ \\
\hline Ingredients of the basal diet: & \\
Barley & 13 \\
Yellow corn & 12 \\
Wheat bran & 25 \\
Soybean meal & 22 \\
Clover hay & 16 \\
Clover straw & 7.45 \\
Molasses & 2.25 \\
Limestone & 1.50 \\
Sodium chloride & 0.30 \\
Vitamin and minerals mixture ${ }^{1}$ & 0.30 \\
DI-methionine & 0.20 \\
Total & $\mathbf{1 0 0 . 0 0}$ \\
\hline
\end{tabular}

\section{Chemical analysis:}

$\begin{array}{lc}\text { CP } & 18.13 \\ \text { CF } & 12.70 \\ \text { EE } & 2.69 \\ \text { NFE } & 65.77 \\ \text { Ash } & 9.71 \\ \text { ME( kcal/kg ration) } & 2502\end{array}$

1 Each kg of vitamin and mineral provides: 4000000 vit. A, 5000000 IU vit D, $16.7 \mathrm{~g}$ vit $E$, $0.67 \mathrm{~g}$ vit. $\mathrm{K}, 0.67 \mathrm{~g}$ vit. B1, $2.0 \mathrm{~g}$ vit. B2, $0.67 \mathrm{~g}$ vit B6, $0.004 \mathrm{~g}$ vit B12, $16.7 \mathrm{~g}$ Niacin, $6.67 \mathrm{~g}$ Pantothinic acid, $0.07 \mathrm{~g}$ Biotine, $1.67 \mathrm{~g}$ Folic acid, $400 \mathrm{~g}$ Choline chloride, $23.3 \mathrm{~g} \mathrm{Zn}, 10 \mathrm{~g}$ $\mathrm{Mn}, 25 \mathrm{~g} \mathrm{Fe}, 1.67 \mathrm{~g} \mathrm{Cu}, 0.25 \mathrm{~g} \mathrm{I}, 0.033 \mathrm{~g}$ Se and $1.33 \mathrm{~g} \mathrm{Mg}$.

Progesterone $\left(\mathrm{P}_{4}\right)$ and prolactin concentration was determined by using RIA kit (Diagnostic Systems Laboratories, Inc., USA) according to the manufacturer information. The levels of serum blood testosterone was also determined by radioimmiunoassay technique, according to the method described by Jaffe and Behrman (1974) and Wilson et al. (1992) using coated kits purchased from Diagnostic Products Corporation Kits, Los Angles, U.S.A.

Data obtained were statistically analyzed according to Snedecor and Cochran (1982), using SPSS (1998). The differences between means were tested using Duncans New Multiple Rang Test (Duncan,1955). 
Pre-weaning mortality percentages were subjected to arc-sin transformation before being analysed in order to approximate normal scale distribution. Means were transformed to the original scale before being illustrated.

\section{RESULTS AND DISCUSSION}

\section{Reproductive efficiency female rabbits:}

\section{a)Doe traits:}

Number of services per conception, gestation length, litter size and litter weight at birth, 21 and at weaning ( 28 days) are presented in Table1.

Litter weight at 21 days and 28 days of age were significantly higher $(P$ $<0.05$ ) with supplemented group at level of $50 \%$ of Bioplex ${ }^{\mathrm{TM}}$ than the treated groups with $25 \%$ and $100 \%$ of Bioplex ${ }^{\mathrm{TM}}$ and untreated does (control), however, number of services per conception, gestation length, litter size at birth, 21 and at weaning (28 days) and litter weight at birth were insignificantly affected by supplementation of Bioplex ${ }^{\mathrm{TM}}$ at different levels. L Copper therapy had improved fertility in sheep as reported by Chruch (1979). Bioplex ${ }^{\mathrm{TM}}$ can be utilized at much lower concentration in the diet than inorganic minerals, without an impact on performance, while also decreasing the excess minerals excretion (Kornegay and Harper, 1977 and Lesen, 2003). Mahan, and Peters, (2004) found that organic trace minerals has been used to increase litter size of sows. Olson et al., (1999) and Muehlenbein et al. (2001)showed no effect of trace mineral source on reproductive performance or calf performance.

The present results indicated that parity had no significant effect on number of services per conception, litter size and liter weight at different age studied (Table 2). Similar results were reported by El-Kelawy (1993).

\section{b) Offspring traits:}

Data in Table 3 show that the effect of supplementation of Bioplex TM on mean bunny weight at birth and at 21 days and litter weight gain from birth up to 28 days were significantly $(P<0.05)$ than the control group. The supplemented group with Bioplex ${ }^{\mathrm{TM}}$ at levels of $50 \%$ being higher significantly than the other groups. However mean bunny weight at 28 days and litter weight gain from 21 to 28 days and pre-weaning mortality rate were not affected significantly by the addition with Bioplex ${ }^{\mathrm{TM}}$.

Mean bunny weight at 21 and 28 days of age and litter weight gain from birth up to 21 and 28 days were not affected significantly by he number of parity of Bouscat doe rabbits. However, mean bunny weight at birth and litter weight gain from 21 to 28 days were significantly $(P<0.05)$. Moreover, Pre-weaning mortality percentage from birth to 28 days were lower significantly $(\mathrm{P}<0.05)$ in the $1^{\text {st }}$ parity than in the $2^{\text {nd }}$ ones. Similar results were reported by Sedki (1991). 
Gad Alla, S.A. et al.

T2-3 


\section{C- Blood biochemical components:}

Data presented in Table 4 show that level of blood serum total protein, urea- $\mathrm{N}$, aspartate aminotransferase (AST), alanine aminotransferase (ALT) were significantly $(P<0.01$ or $P<0.05)$ higher in doe rabbis supplemented with Bioplex ${ }^{\mathrm{TM}}$. However, level of blood serum total lipids, and cholesterol were significantly lower $(P<0.01)$ in rabbits treated with $50 \%$ and $100 \%$ Bioplex ${ }^{\mathrm{TM}}$ as compared to those of treated with $25 \%$ Bioplex $^{\mathrm{TM}}$ or those of the control group. Levels of blood serum creatinine, serum blood minerals $(\mathrm{Ca}, \mathrm{P}$, $\mathrm{K}, \mathrm{Na}, \mathrm{Ca} / \mathrm{P}$ and $\mathrm{Na} / \mathrm{K}$ ) and serum blood hormones (progesterone and prolactin) were not affected significantly by supplemental levels of Bioplex ${ }^{\mathrm{TM}}$. Although, statistical analysis revealed significant effect of additional levels of Bioplex ${ }^{\mathrm{TM}}$ on serum total protein, total lipids, cholesterol, urea- $\mathrm{N}$, aspartate aminotransferase (AST), alanine aminotransferase (ALT) however, the differences in these components between groups were within the normal physiological range. Aforementioned results of blood serum components demonstrated that adding supplemental levels of Bioplex ${ }^{\mathrm{TM}}$ in the diet of doe rabbis had no adverse effect on liver and kidneys functions of all rabbit groups. Similar results were obtained by Abd El-Rahim et al. (1996) who found hat serum calcium and magnesium concentration were no influenced significantly by increasing the dietary Fe levels.

Table 4. Effect of commercial organic trace minerals (Bioplex) on blood constituents $(X \pm S E)$ of doe Bauscat rabbits.

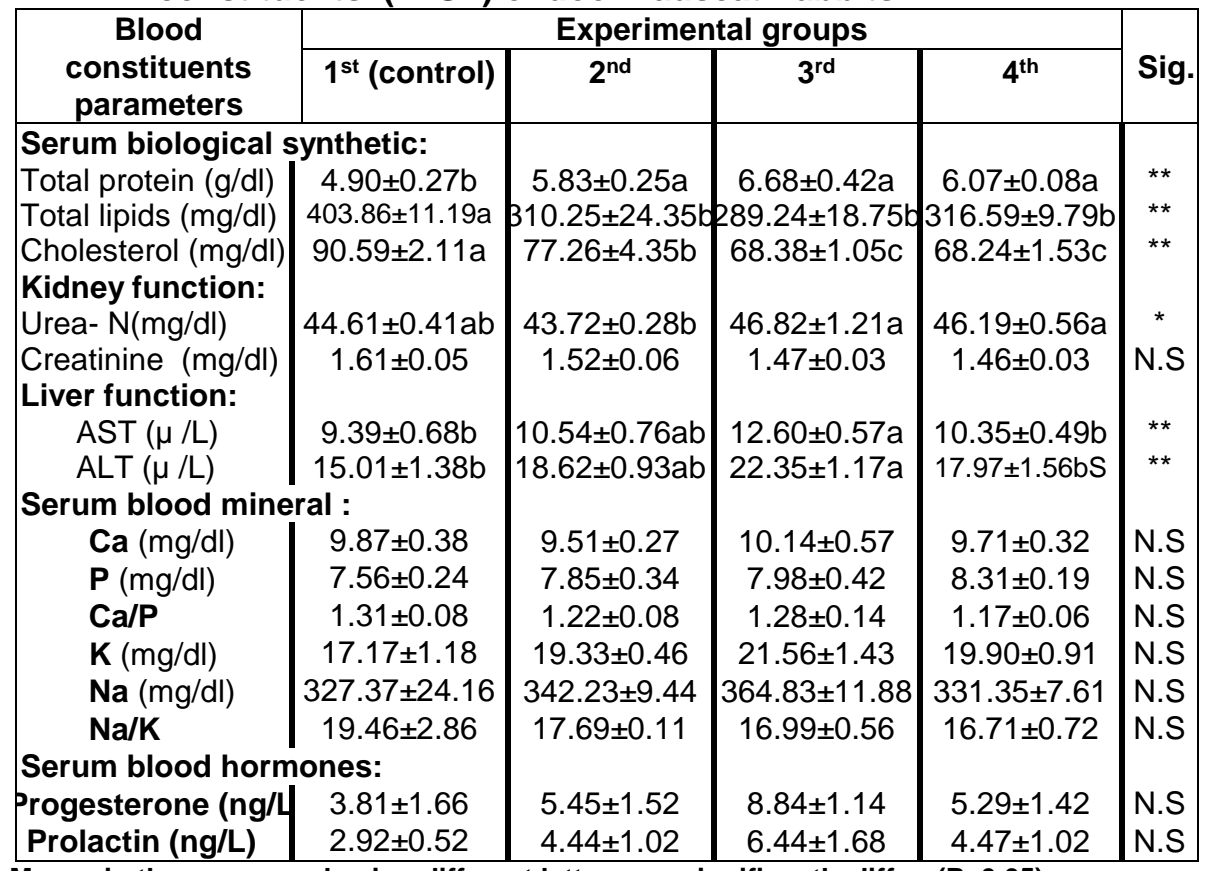

Means in the same row having different letters are significantly differ, $(P<0.05)$.

${ }^{*}=\mathrm{P}<0.05, \mathrm{~N} . \mathrm{S}=$ Not significant. 
Gad Alla, S.A. et al.

\section{Reproductive efficiency of male rabbits:}

a) Physical semen characteristics:

Data in Table 5 show that supplementation of Bioplex ${ }^{\mathrm{TM}}$ significantly $(P<0.01$ or $P<0.05)$ improved semen quality of buck rabbits. In this respect, ejaculate volume, wave motion, sperm motility and total sperm out put were increased, while dead and abnormal spermatozoa were decreased in semen of bucks given supplemental level of Bioplex'M than the control one. However, the buck rabbits received the additional level of $100 \%$ Bioplex $^{\mathrm{TM}}$ showed the best physical semen characteristics as compared to buck rabbits received the additional level of $25 \%$ and $50 \%$ of Bioplex ${ }^{\mathrm{TM}}$. The effect of dietary zinc level on quality of semen may be attributed to the fact that sufficient zinc is required for the spermatogenesis, especially during the final stage of maturation (Underwood and Somers, 1977) and prevent the destruction of spermatozoa DNA by inhibiting deoxyribonuclase activity in semen (Quinn, 1968).Sufficient zinc is also necessary for genital glands under the effect of testosterone (Hidrioglou, et al., 1987).

Table 5: Semen characteristics of buck Bouscat rabbits as affected by commercial organic minerals (Bioplex ${ }^{\mathrm{TM}}$ ).

\begin{tabular}{|c|c|c|c|c|c|}
\hline Treatments (T): & Control & $250 \mathrm{mg}$ & $500 \mathrm{mg}$ & $1000 \mathrm{mg}$ & g. \\
\hline Ejaculate volume (ml) & $0.61 \pm 0.04^{b}$ & $0.69 \pm 0.03^{a b}$ & $0.88 \pm 0.08^{a}$ & $0.81 \pm 0.08^{a}$ & * \\
\hline Wave motion (score) & $2.80 \pm 0.17^{b}$ & $3.47 \pm 0.19^{a}$ & $3.33 \pm 0.23^{a b}$ & $2.87 \pm 0.19^{b}$ & * \\
\hline Sperm motility (\%) & $52.00 \pm 0.28^{b}$ & $60.00 \pm 2.58^{\mathrm{ab}}$ & $61.33 \pm 3.50^{a}$ & $56.67 \pm 2.52^{\mathrm{ab}}$ & NS \\
\hline Dead spermatozoa (\%) & $17.33 \pm 0.68^{a}$ & $11.93 \pm 0.56^{b}$ & $13.73 \pm 0.75^{b}$ & $12.33 \pm 0.59^{b}$ & * \\
\hline $\begin{array}{l}\text { Abnormal } \\
\text { spermatozoa }\end{array}$ & $15.27 \pm 0.61^{a}$ & $12.00 \pm 0.44^{b}$ & $11.73 \pm 0.68^{b}$ & $11.47 \pm 0.71^{b}$ & * \\
\hline $\begin{array}{l}\text { Sperm concentration } \\
\left(\times 10^{6} / \mathrm{ml}\right)\end{array}$ & $244.00 \pm 6.21$ & $244.00 \pm 6.21$ & $265.27 \pm 11.41$ & $259.20 \pm 7.10$ & NS \\
\hline $\begin{array}{l}\text { Total sperm out pout } \\
\text { (106/ejaculate) }\end{array}$ & $148.75 \pm 9.02^{c}$ & $73.91 \pm 5.64^{\mathrm{abc}}$ & & $04.05 \pm 15.93^{a b}$ & ** \\
\hline
\end{tabular}

\section{b) Blood biochemical components:}

Data presented in Table 6 show that level of blood serum cholesterol and ALT were significantly $(P<0.05$ or $P<0.01)$ lower in the buck rabbits fed diets supplemented with the level of $100 \%$ of Bioplex ${ }^{\mathrm{TM}}$ than the other groups. However, levels of blood serum AST significantly $(\mathrm{P}<0.05)$ higher in the buck rabbits fed diets supplemented with the level of $100 \%$ of Bioplex ${ }^{\mathrm{TM}}$ than the other groups. However, the indicated levels were within the normal physiological range of rabbis (Faavorato and Zata, 1990). Levels of total protein, total lipids, urea- $\mathrm{N}$, creatinine, serum blood minerals $(\mathrm{Ca}, \mathrm{P}, \mathrm{K}, \mathrm{Na}$, $\mathrm{Ca} / \mathrm{P}$ and $\mathrm{Na} / \mathrm{K}$ ) and testosterone were statistically similar among groups. Similar results were obtained by Abd El-Rahim et al. (1996) who found hat 
serum calcium and magnesium concentration were no influenced significantly by increasing the dietary Fe levels.

Table 6. Effect of commercial organic trace minerals (Bioplex ${ }^{\mathrm{TM}}$ ) on blood constituents $(X \pm S E)$ of buck Bauscat rabbits.

\begin{tabular}{|c|c|c|c|c|c|}
\hline \multirow{2}{*}{$\begin{array}{c}\text { Blood constituents } \\
\text { parameters }\end{array}$} & \multicolumn{4}{|c|}{ Experimental groups } & \multirow{2}{*}{ Sig. } \\
\hline & $1^{\text {st }}$ (control) & $2^{\text {nd }}$ & $3^{\text {rd }}$ & $4^{\text {th }}$ & \\
\hline \multicolumn{2}{|c|}{ Serum biological synthetic: } & \multirow[b]{2}{*}{$5.83 \pm 0.31$} & \multirow[b]{2}{*}{$6.54 \pm 0.86$} & \multirow[b]{2}{*}{$6.81 \pm 0.47$} & \multirow[b]{2}{*}{ N.S } \\
\hline Total protein (g/dl) & $5.20 \pm 0.10$ & & & & \\
\hline Total lipids (mg/dl) & \multicolumn{4}{|c|}{$422.77 \pm 13.73 \mathrm{a} 323.39 \pm 24.91311 .15 \pm 19.34342 .17 \pm 21.56$} & N.S \\
\hline Cholesterol (mg/dl) & $92.17 \pm 2.06 a$ & $80.92 \pm 4.41 b$ & $72.67 \pm 2.36 b c$ & $71.09 \pm 1.50 \mathrm{c}$ & ** \\
\hline \multicolumn{6}{|l|}{ Kidney function: } \\
\hline Urea- N(mg/dl) & $47.16 \pm 0.75$ & $46.59 \pm 0.38$ & $47.66 \pm 1.97$ & $45.18 \pm 0.64$ & N.S \\
\hline Creatinine (mg/dl) & $1.56 \pm 0.06$ & $1.45 \pm 0.06$ & $1.41 \pm 0.04$ & $1.38 \pm 0.03$ & N.S \\
\hline \multicolumn{6}{|l|}{ Liver function: } \\
\hline AST $(\mu / L)$ & $8.92 \pm 0.60 b$ & $10.03 \pm 0.75 a b$ & $12.09 \pm 0.56 a$ & $9.73 \pm 0.71 b$ & * \\
\hline $\operatorname{ALT}(\mu / L)$ & $16.47 \pm 1.00 b$ & $19.79 \pm 1.02 a b$ & $23.14 \pm 1.32 a b$ & $19.43 \pm 1.74 a$ & * \\
\hline \multicolumn{2}{|c|}{ Serum blood mineral : } & & & & \\
\hline Ca $(\mathrm{mg} / \mathrm{dl})$ & $8.87 \pm 0.38$ & $8.51 \pm 0.27$ & $9.14 \pm 0.57$ & $8.71 \pm 0.32$ & N.S \\
\hline $\mathbf{P}(\mathrm{mg} / \mathrm{dl})$ & $6.19 \pm 0.85$ & $7.39 \pm 0.31$ & $7.69 \pm 0.47$ & $8.03 \pm 0.27$ & N.S \\
\hline $\mathrm{Ca} / \mathrm{P}$ & $1.50 \pm 0.25$ & $1.16 \pm 0.07$ & $1.21 \pm 0.14$ & $1.09 \pm 0.07$ & N.S \\
\hline $\mathbf{K}(\mathrm{mg} / \mathrm{dl})$ & $16.04 \pm 1.27$ & $18.61 \pm 0.84$ & $20.59 \pm 1.55$ & $18.98 \pm 0.96$ & N.S \\
\hline $\mathrm{Na}(\mathrm{mg} / \mathrm{dl})$ & $345.50 \pm 26.84$ & $357.32 \pm 7.40$ & $384.31 \pm 9.67$ & $351.30 \pm 6.63$ & N.S \\
\hline $\mathrm{Na} / \mathrm{K}$ & $22.09 \pm 3.56$ & $19.24 \pm 0.55$ & $18.81 \pm 0.94$ & $18.59 \pm 0.93$ & N.S \\
\hline \multicolumn{6}{|l|}{ Serum } \\
\hline testesterone(ng/L) & $5.67 \pm 1.11$ & $5.77 \pm 0.76$ & $6.68 \pm 0.42$ & $6.44 \pm 0.79$ & N.S \\
\hline
\end{tabular}

Means in the same row having different letters are significantly differ, $(P<0.05)$. ${ }^{*}=P<0.05,{ }^{* \star}=P<0.01$ and N.S= Not significant.

In conclusion, the results of the study clarified that supplementation of Bioplex $^{\mathrm{TM}}$ had beneficial effect on reproductive efficiency of male and female Bouscat rabbits. Future research will focus on effects of reduced mineral diets to improve reproductive efficiency of rabbis. 
Gad Alla, S.A. et al.

\section{REFERENCES}

Abdel Mageed, A. B. and Oehme, F. W. (1990). A review of the biochemical roles, toxicity and interaction of zinc, copper and iron: 1. Zinc. Veterinary Human Toxicology, 32: (1), 34-39.

AbdEI-Rahim M. I.;El-Kerdawy Dawlat, A.; El-Kelawy, H. M. and Abdalla Fatma,R. (1996). Bioavalibility of iron in growing rabbits fed excess levels of dietary iron,under Egyptian conditions. 6Wrld Rabbit Congress Tolouse, 1: 51-57.

Apgar,J. (1971). Effect of low zinc diet during gestation on reproduction in the rabbit. Journal of Anim. Sci., 33: 1255- 1258.

A.O.A.C. (1990). Association of Official Analytical Chemists, "Official Methods of Analysis". 13 ${ }^{\text {th }}$ Ed. Published by the A. O. A .C., Benjamen Franklin Station, Washington, D. C.

Banerjee, G. C. (1988). Feeds and Principles of Animals Nutrition. $2^{\text {nd }}$ Edition, Oxford and IBH Publishing Co. PVT. LTD.

Barceloux,D. G. (1999). Zinc. Toxicol, Clin. Toxicol., 37: 2, 279-292.

Besser, J. M. 2001. Early life-stage toxicity of copper to endangered and surrogate fish species. U.S. Environmental Protection Agency, Washington, D.C.

Church,D.C. (1979). Rabbi Feeding and Nutrition. Academic Press, Inc. Oregon.

Duncan, D.B.(1955).Multiple Range and Multiple F-Test. Biometrics, 11: 142.

El-Gaafary, M. N. (1987). The characteristics of semen from Welsh Mountain and Cambridge rams. Ph.D. Thesis, University, College of North Wales, Bangor, U. K.

El-Kelawy, H.M. (1993). Studies on reproductive and productive performance in rabbits. Ph. D. Thesis, Faculty of Agriculture, Zagazig Univ., Egypt.

Favorato, M. and Zatta, P. (1990). Chemico-clinical characterization of rabbit serum. Journal of Applied Rabbit Research, 13: 14-15.

Fizgerald, J.A. ; Everett, J. A. and Apgar, J. (1986). Effect of low zinc intake during pregnancy on plasma prolactin, progesterone, prostaglandin, cortisol and protein concentrations of ewes during the preiparturient period. Canadian Journal of Anim. Sci., 66: 643-651..

Gross,R. L. ; Osolin, N.; Fong, L. and Newberne, P. N. (1979). Depressed immunological function in zinc dprived rates as measured by nitrogen response of spleen, thymus and prepheral blood. American Journal of Clinical Nutrition.32: 1260-1266.

Hahn, J. D and Baker,D. H. (1993). Growth and plasma zinc responses of young pigs fed pharmacological levels of zinc, Journal of Anim. Sci., 71: 3020-3024.

Henry, R.J. (1964). Clinical Chemistry. Harper and Row Publishers, New York pp: 181.

Henry, R.J. (1974). Clinical Chemistry, Principles and Techniques., $2^{\text {nd }}$ edition, Harper and Row, pp: 525.

Hidiroglou, M.; A.J. McAllister and C.J. Williams (1987). Prepartum supplementation of selenium and vitamin $\mathrm{E}$ to dairy cows: Assessment 
of selenium status and reproductive performance. Journal of Dairy Science, 70: 1281.

Jaffe, B.M. and Behrman, N. R. (1974). Method of hormone radioimmunoassay. Academic press.

King, J.O.L.(1970). The feeding of copper sulfate to growing rabbits. British, Veterinary Journal, 131:70.

Kornegay, E. T. and A. F. Harper. 1997. Environmental nutrition: nutrient management strategies to reduce nutrient excretion of swine. J. Anim. Sci. 13:99-111.

Lang,J. (1981). The nutrition of the commercial rabbit part 1. Physiology, digestibility and nutrient requirements. Common wealth bureau of nutrition. Nutr. Abst. Rev.Series.p., 51: 197.

Leeson, S. 2003. A new look at trace mineral nutrition of poultry: can we reduce environmental burden of poultry manure? In: Nutritional Biotechnology in the Feed and Food Industries. T. P. Lyons and K. A. Jacques Eds. Nottingham University Press, Nottingham, United Kingdom.

Leonhard-Marek, S. (2000).Why do trace elements have an influence on fertility? Tieraztliche Parxis Ausgabe-G,Grossiere Nuztiere,28:2,60-65.

Mahan, D. C. and J. C. Peters. 2004. Long-term effects of dietary organic and inorganic selenium sources and levels on reproducing sows and their progeny. J. Anim. Sci. 82:1343-1358.

Muehlenbein, E. L., D. R. Brink, G. H. Deutscher, M. P. Carbon, and A. B. Johnson. 2001. Effects of inorganic and organic copper supplemented to first-calf cows on cow reproduction and calf health and performance. J. Anim. Sci. 79:1650.

N.R.C. (1977). Nutrient Requirements of Rabbits. 2nd Review. Edition. National Academy Science, USA. Ca pp 30.

Olson, P. A., D. R. Brink, D. T. Hickok, M. P. Carlson, N. R. Schneider, G. H. Deutscher, D. C. Adams, D. J. Colburn, and A. B. Johnson. 1999. Effects of supplementation of organic and inorganic combinations of copper, cobalt, manganese, and zinc above nutrient requirement levels on postpartum two-year old cows. J. Anim. Sci. 77: 522.

Quinn,P.J.(1968). Deoxyribonuclase activity in semen. Journal of Reproduction and Fertility, 17:35.

Reitman, S. and Frankel, S. (1957). Determination of serum glutamic oxaloacetic and serum pyruvic transaminases. Am. J. Clin. Path., 28: 56-60.

Sedki (1991). Some behavioural studies on rabbits. M.Sc. Thesis, Faculty of Agriculture, Zagazig Universiy, Zagazig, Egypt.

Snedecor, G.W. and Cochran, W.G. (1982). Statistical Methods. $7^{\text {th }}$ Edition. lowa State. University, Press, USA.

SPSS (1998). User's Guide Statistics Version, 8. Copyright SPSS Inc. USA.

Underwood, E.J. and Somers,M. (1977). Zinc in" Trace Element in Human and Animal Nutrition" $4^{\text {th }}$ Edition Academic Press, New York, SanFrancissco and London,196: 212.

Wilson, J.D., Foster, D. W. and Williams, D. (1992). Text book of Endocrinology of Ram Spermatozoa. Small. Anim. Parc. 54: 481-486. 


\section{Gad Alla, S.A. et al.}

Youdin, M. B. and Green, A. R. (1977).' liron metabolism" Ciba Foundation symposium 51, New Series, 201-221 pp. Elsevier, Exerpta Medica and North Holland, Amsterdam, Oxford, New York.

\section{أملاح العليقة وتأثيرها علي الصفات الإنتاجية والتناسلية في الأرانب تحت ظرف \\ صلاح عبد الحكيم جاد الله، عبدالمنعم صدقي، مختار أبو العلا و حمدي عبدالعزيز أبو

$$
\text { معهذ بحوث الإنتاج الحيواني ـ مركز البحوث الزراعية - وزارة الزراعة. }
$$

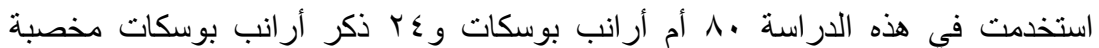

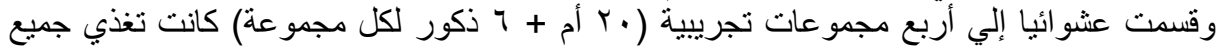

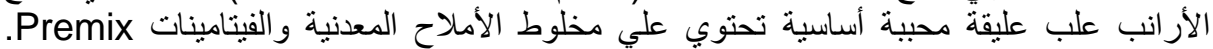

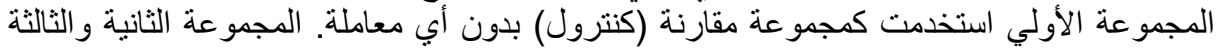

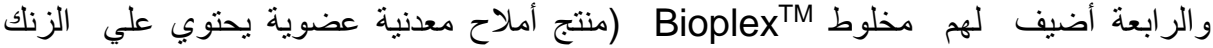

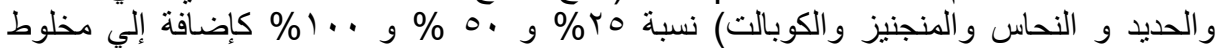

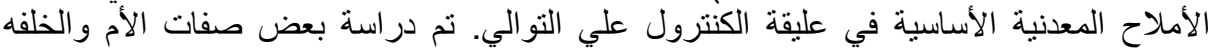

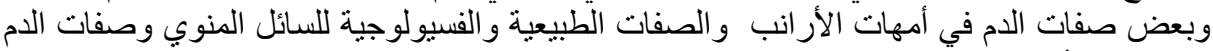

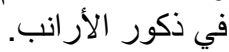

أوضحت النتائج المتحصل عليها أن:

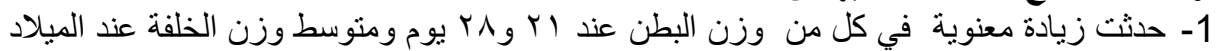

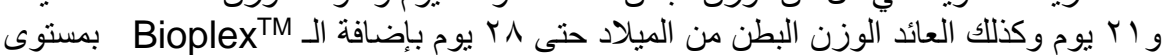

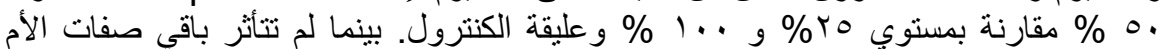

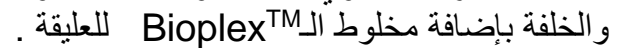

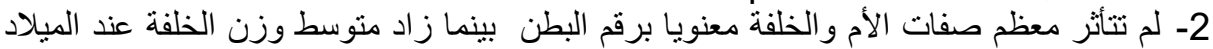

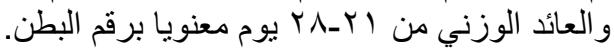

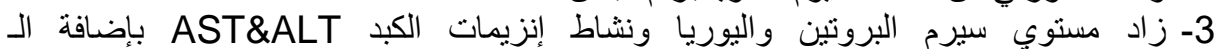

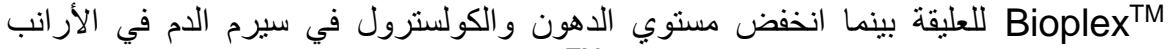

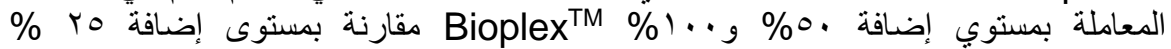

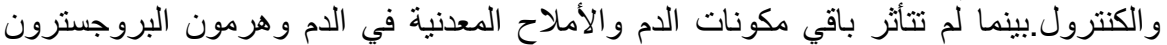

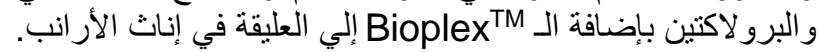

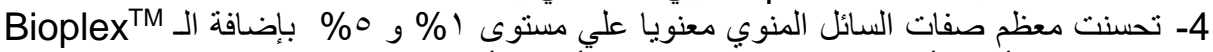

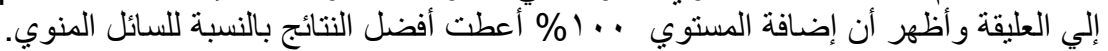
5- كانت نشاط إنزيمات الكبد

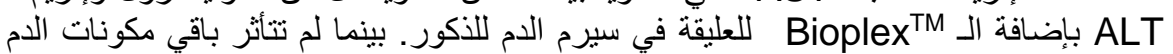
و الأملاح المعدنية في الدم وهرمون التستسترون في سيرم الدم للأكور. 
Table 2: Doe traits of Bouscat rabbits as affected by commercial organic minerals (Bioplex ${ }^{\mathrm{TM}}$ ).

\begin{tabular}{|c|c|c|c|c|c|c|c|c|c|}
\hline \multirow[b]{2}{*}{ Items } & \multirow{2}{*}{$\begin{array}{l}\text { No } \\
\text { of } \\
\text { doe }\end{array}$} & \multirow{2}{*}{$\begin{array}{c}\text { Number of } \\
\text { services per } \\
\text { conception (\%) }\end{array}$} & \multirow{2}{*}{\begin{tabular}{|c|}
$\begin{array}{c}\text { Gestation } \\
\text { length } \\
\text { (days) }\end{array}$ \\
\end{tabular}} & \multicolumn{3}{|c|}{ Liter size } & \multicolumn{3}{|c|}{ Litter weight } \\
\hline & & & & Birth & $\begin{array}{c}21 \\
\text { days }\end{array}$ & $\begin{array}{c}28 \\
\text { days }\end{array}$ & Birth & $\begin{array}{c}21 \\
\text { days }\end{array}$ & $\begin{array}{c}28 \\
\text { days }\end{array}$ \\
\hline \multicolumn{10}{|c|}{ Treatments (T): } \\
\hline Control & 20 & $1.72 \pm 0.16$ & $30.90 \pm 0.12$ & $5.20 \pm 0.25$ & $5.11 \pm 0.24$ & $4.89 \pm 0.24$ & $295.00 \pm 12.81$ & $1355.00 \pm 21.97^{\mathrm{b}}$ & $2006.11 \pm 63.91^{\mathrm{b}}$ \\
\hline $250 \mathrm{mg}$ & 20 & $1.61 \pm 0.14$ & $31.00 \pm 0.18$ & $5.53 \pm 0.45$ & $5.37 \pm 0.45$ & $5.00 \pm 0.47$ & $338.75 \pm 25.47$ & $1484.38 \pm 124.98^{\mathrm{ab}}$ & $2231.87 \pm 179.50^{\mathrm{ab}}$ \\
\hline $500 \mathrm{mg}$ & 20 & $1.31 \pm 0.11$ & $31.00 \pm 0.009$ & $6.18 \pm 0.41$ & $5.55 \pm 0.34$ & $5.27 \pm 0.34$ & $360.45 \pm 20.06$ & $1657.27 \pm 77.34^{\mathrm{a}}$ & $2407.73 \pm 83.87^{a}$ \\
\hline $1000 \mathrm{mg}$ & 20 & $1.45 \pm 0.14$ & $30.40 \pm 0.11$ & $5.90 \pm 0.39$ & $5.30 \pm 0.31$ & $5.10 \pm 0.28$ & $334.00 \pm 20.45$ & $1448.00 \pm 63.58^{\mathrm{ab}}$ & $2105.00 \pm 49.24^{\mathrm{b}}$ \\
\hline Significance & & NS & NS & NS & NS & NS & \begin{tabular}{|c|} 
NS \\
\end{tabular} & * & ${ }^{*}$ \\
\hline \multicolumn{10}{|l|}{ Parity (P): } \\
\hline $1^{\text {st }}$ parity & 40 & $1.39 \pm 0.8$ & $31.00 \pm 0.10$ & $5.60 \pm 0.26$ & $5.20 \pm 0.25$ & $5.05 \pm 0.25$ & $334.25 \pm 14.42$ & $1496.00 \pm 62.87$ & $2157.25 \pm 82.24$ \\
\hline $2^{\text {nd }}$ parity & 40 & $1.62 \pm 0.11$ & $30.63 \pm 0.08$ & $5.89 \pm 0.29$ & $5.50 \pm 0.21$ & $5.11 \pm 0.22$ & $330.53 \pm 14.21$ & $1492.22 \pm 48.86$ & $2238.89 \pm 58.41$ \\
\hline Significance & & NS & $*$ & NS & NS & NS & \begin{tabular}{|c|} 
NS \\
\end{tabular} & NS & NS \\
\hline
\end{tabular}

Means in the same row having different letters are significantly differ, $(\mathrm{P}<0.05)$.

${ }^{*}=P<0.05$ and N.S= Not significant.

Table 3: Offspring traits of Bouscat rabbits as affected by commercial organic minerals (Bioplex ${ }^{\mathrm{TM}}$ ).

\begin{tabular}{|c|c|c|c|c|c|c|c|c|c|}
\hline \multirow{2}{*}{ Items } & \multicolumn{3}{|c|}{ Mean bunny weight } & \multicolumn{3}{|c|}{ Litter weight gain } & \multicolumn{3}{|c|}{ Mortality rate (\%) } \\
\hline & Birth & 21 days & 28 days & Birth-21 & Birth -28 days & 21-28 days & Birth & 21days & 28 days \\
\hline \multicolumn{10}{|c|}{ Treatments $(\mathbf{T}):$} \\
\hline Control & $57.21 \pm 1.12$ & $272.13 \pm 9.28$ & $424.30 \pm 21.07$ & $1056.67 \pm 13.02$ & $1707.78 \pm 51.93$ & $561.11 \pm 45.21$ & 4.63 & 8.17 & 4.36 \\
\hline $250 \mathrm{mg}$ & $60.72 \pm 2.00$ & $280.34 \pm 13.34$ & $458.86 \pm 17.16$ & $1145.63 \pm 100.96$ & $1893.13 \pm 155.85$ & $747.50 \pm 61.20$ & 7.81 & 12.97 & 7.41 \\
\hline $500 \mathrm{mg}$ & $59.49 \pm 1.05$ & $305.01 \pm 5.76$ & $481.38 \pm 20.65$ & $1296.82 \pm 59.92$ & $2047.27 \pm 67.37$ & $750.45 \pm 44.54$ & 11.23 & 13.18 & 4.87 \\
\hline $1000 \mathrm{mg}$ & $56.99 \pm 0.78$ & $280.34 \pm 8.63$ & $432.34 \pm 20.04$ & $1114.00 \pm 50.09$ & $1771.00 \pm 36.26$ & $657.00 \pm 46.77$ & 11.76 & 11.11 & 3.09 \\
\hline Significance & * & * & NS & * & * & NS & NS & NS & NS \\
\hline \multicolumn{10}{|l|}{ Parity (P): } \\
\hline $1^{\text {st }}$ parity & $60.19 \pm 0.98$ & $294.09 \pm 6.96$ & $445.63 \pm 14.95$ & $1161.75 \pm 50.31$ & $1823.00 \pm 70.15$ & $661.25 \pm 37.68 b$ & 9.72 & 10.05 & 2.68 \\
\hline $2^{\text {nd }}$ parity & $56.75 \pm 0.66$ & $276.04 \pm 5.87$ & $455.31 \pm 13.99$ & $1185.05 \pm 37.91$ & $1904.72 \pm 47.25$ & $746.67 \pm 29.80 a$ & 8.39 & 12.90 & 7.19 \\
\hline Significance & * & NS & NS & NS & NS & * & NS & NS & * \\
\hline
\end{tabular}

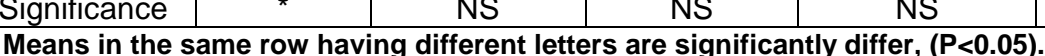

${ }^{*}=P<0.05$ and N.S $=$ Not significant. 